\title{
TELAAH KRITIS TERHADAP PRAKTIK PERKAWINAN DI BAWAH TANGAN DI INDONESIA
}

\author{
Ghufron Maksum \\ Sekolah Tinggi Agama Islam Nurul Iman Parung-Bogor \\ Jl. Nurul Iman No. 01 Ds. Waru Jaya rt.01/01 Kec. Parung, Kab. Bogor \\ email: ghufronelutsmani@gmail.com
}

\begin{abstract}
Critical Review of Unregistered Marriage In Indonesia. Most people believe that unregistered marriage is legal in Islam because it has completely the pillars and requeirement of marriage, even if the marriage is not registered in the Office of Religious Affairs (KUA). As a result of this understanding, the dualism of law arising in this Indonesia country, on one side of the marriage must be registered on the KUA and the other side without registered also remains valid and recognized in the society. Therefore, it is necessary to study research critically to the pillars of marriage in which pillars of marriage is still disputed by the leaders of four madzhab so maybe made the new ijtihad caused by the changing situation and condition in society that require to the benefit. This study concluded that the registering is one of the pillars of marriage. Every marriage must be registered before the marriage registrar. Marriages that are not registered (unregistered marriage) will bring chaos and harmful. Such marriage is forbidden (illegal) because it is inconsistent with the maqâshid al-syarîah.
\end{abstract}

Keywords: Marriage, Marriage Regristration, Islamic Law

\begin{abstract}
Abstrak: $\quad$ Telaah Kritis terhadap Praktik Perkawinan di Bawah Tangan di Indonesia. Kebanyakan orang meyakini bahwa perkawinan di bawah tangan sah menurut Islam karena telah memenuhi rukun dan syaratnya, sekalipun perkawinan tersebut tidak dicatatkan di Kantor Urusan Agama (KUA). Akibat pemahaman tersebut maka timbul dualisme hukum yang berlaku di negara Indonesia ini, yaitu di satu sisi perkawinan itu harus dicatatkan di KUA dan disisi lain tanpa dicatatkan pun tetap berlaku dan diakui dimasyarakat. Oleh karena itu perlu adanya kajian yang menela'ah secara kritis terhadap rukun perkawinan yang ada yang mana rukun perkawinan tersebut masih diperselisihkan oleh para Imam Madzhab yang empat sehingga dimungkinkan adanya ijtihad baru disebabkan karena perubahan situasi dan kondisi masyarakat yang menuntut kemaslahatan. Penelitian ini menyimpulkan bahwa pencatatan merupakan salah satu dari rukun perkawinan. Setiap perkawinan harus dicatatkan dihadapan petugas pencatat nikah. Perkawinan yang tidak dicatatkan (di bawah tangan) akan mendatangkan kekacauan dan kemadharatan. Perkawinan seperti ini hukumnya haram (tidak sah) karena tidak sejalan dengan maqâshid al-syarîah.
\end{abstract}

Kata kunci: Perkawinan, Pencatatan Perkawinaan, Hukum Islam 


\section{Pendahuluan}

Sebagaimana telah dijelaskan oleh Allah Swt dalam Al-Qur'an surat Al-Nisầ ayat 3 yang menyatakan seorang laki-laki boleh melaksanakan perkawinan dengan dua, tiga, atau empat wanita sekaligus, tetapi jika khawatir tidak dapat berlaku adil, maka cukup satu saja. ${ }^{1}$ Begitu juga dalam hadits Nabi Saw. yang berbunyi "Nikah itu adalah sunabku, barang siapa yang tidak mencintai sunabku maka dia bukan termasuk golonganku"2. Dengan demikian jika ditanyakan apa motif beristri lebih dari satu orang, kebanyakan orang akan menjawab adalah sunnah Nabi, karena Nabi juga beristri lebih dari satu orang. Jawaban tersebut di atas, hanya sekedar membela diri untuk beristri lebih dari satu orang, padahal kalau diteliti secara mendalam, Nabi beristri lebih dari satu orang hanya untuk berdakwah mengembangkan agama Islam atau melindungi hak-hak wanita setelah ditingal mati suaminya dari medan perang.

Perkawinan Nabi dengan Siti Khadijah, karena Siti Khadijah orang kaya dan terpandang yang bisa dijadikan sebagai tulang punggung untuk berdakwah, perkawinan Nabi dengan Siti Aisyah karena Siti Aisyah orang yang cerdas dan masih muda, sehingga dari Siti Aisyah diharapkan bisa melahirkan keturunan, dari Siti Aisyah pula terkumpul hadits- hadits hukum. Perkawinan Nabi dengan Mariyah Al-Qibtiyyah ${ }^{3}$ adalah untuk menjalin hubungan persahabatan dengan kerajaan Romawi di Mesir, karena Mariyah Al-Qibtiyyah adalah hadiah dari Gubernur Mukaukis di Mesir, dengan hubungan persahabatan tersebut yang akhirnya Islam begitu mudah masuk Mesir. Begitu juga perkawinan Nabi dengan Siti Sa'udah, hanya sekedar melindungi hak-haknya karena Siti Sa'udah telah ditinggal mati oleh suaminya di medan perang.

Kalau menyimak dari perkawinan Nabi tersebut di atas, dapat disimpulkan bahwa pekawinan Nabi Saw. lebih dari satu wanita (poligami) bukan karena sex, tetapi karena ada tujuan-tujuan tertentu, yaitu untuk berdakwah, memajukan Islam dan memperkuat barisan Islam, karena pada saat itu umat muslim masih sedikit. Sedangkan perkawinan lebih

${ }^{1}$ Lihat QS. Al-Nisâ’[4]: 3

${ }^{2}$ Lihat Sunan Ibnu Majjah No. 1836

${ }^{3}$ Mariyah al-Qibtiyyah binti Sham'un, berasal dari daerah Ansena, Ashut, Mesir. Seorang hamba sahaya yang dihadiahkan oleh Gubernur Mesir, Mukaukis, setelah perang Khaibar. Melalui Mariyah al-Qibtiyyah, Nabi SAW. dikarunia putra yang diberi nama Ibrahim. Lihat Ahmad Lutfi Fathullah, Potret Kehidupan Pribadi Dan Kehidupan Rasulullah Saw. (Jakarta: Pusat Kajian Hadits) 
dari satu wanita yang dilakukan pria sekarang hanya kerena sex, hal itu bisa dilihat karena pria sekarang yang melakukan perkawinan lebih dari satu wanita biasanya memilih wanita yang lebih muda atau lebih cantik dari istri pertama. Oleh karena itu tujuan poligami yang dilakukan oleh pria sekarang berbeda dengan tujuan poligami pada zaman Nabi Saw. Begitu juga poligami yang diajarkan oleh Nabi bersifat terbuka, artinya perkawinan-perkawinan Nabi selalu diketahui dan diizinkan oleh istri-istri sebelumnya, sedangkan poligami pria sekarang biasanya untuk istri ke dua, ke tiga dan seterusnya secara sembunyi-sembunyi (tidak dicatatkan di KUA), yang istilah populernya disebut dengan perkawinan di bawah tangan atau kawin siri.

Perkawinan di bawah tangan atau yang lazim dikenal dengan kawin siri atau kawin tidak resmi merupakan perkawinan yang terpenuhi semua rukun dan syarat yang ditetapkan dalam fikih (hukum Islam) namun tanpa pencatatan resmi di instansi yang berwenang sebagaimana yang diatur dalam peraturan perundang-undangan suatu Negara. ${ }^{4}$ Perkawinan yang seperti dikemukakan tersebut sering kali menimbulkan madharat terhadap istri atau anak yang dilahirkan terkait dengan hak-hak mereka seperti nafkah, hak waris dan lain sebagainya.

Tujuan perkawinan adalah untuk memenuhi tuntutan naluri manusia yang asasi, untuk membentengi akhlak mulia, menegakkan rumah tangga yang bernuansa islami, meningkatkan ibadah kepada Allah swt, dan untuk mencari keturunan yang shaâlih dan shâlihbah. ${ }^{5}$ Perkawinan sudah dianggap sah jika telah memenuhi syarat dan rukun nikah, yaitu jika ada calon suami, calon istri, wali nikah, dua orang saksi, dan ijab kabul. ${ }^{6}$ Untuk menguatkan dan menjamin kepastian hukum perkawinan para pihak dapat dilindungi oleh Negara maka perkawinan yang dilangsungkan harus dilaksanakan di hadapan petugas yang berwenang, agar perkawinan tersebut dapat dicatat sebagai perkawinan yang sah secara hukum negara.

Sebagaimana telah disebutkan dalam pasal 2 ayat (2) Undang-undang

${ }^{4}$ Asrorun Niam Sholeh, Fatwa-fatwa Masalah Pernikahan dan Keluarga (Jakarta: eLSAS, 2008), h. 49.

5 Muhammad Fuâd Abd al-Bâqi, al-Mujjam al-Mufahras li al-Fâdz al-Qur'ân al-Karîm (Beirut: Dâr al-Fikr, 1987), 332-333.

${ }^{6}$ Amir Nuruddin dan Azhari Akmal Tarigan, Hukum Perdata Islam di Indonesia (Jakarta: Fajar Interpratama Offset, 2004), h. 2 
Perkawinan nomor 1 tahun 1974, yaitu "tiap-tiap perkawinan dicatat menurut peraturan peraturan perundang-undangan yang berlaku". Begitu juga pada pasal 4 dan 5 dalam undang-undang yang sama berbunyi “ Dalam hal seorang suami akan beristri lebih dari seorang (poligami), maka ia wajib mengajukan permohonan ke- Pengadilan di daerah tempat tinggalnya, dengan ketentuan jika istri tidak dapat menjalankan kewajibannya sebagai istri, istri mendapat cacat badan atau penyakit yang sulit untuk disembuhkan dan istri tidak dapat melahirkan keturunan, disamping itu harus ada persetujuan dari istri pertamanya. Atau ada jaminan bahwa suami akan berlaku adil terhadap istri dan anak-anak mereka. $^{7}$

Selama ini perkawinan di bawah tangan (kawin siri) banyak terjadi di Indonesia, baik dikalangan masyarakat biasa, para pejabat ataupun para artis, istilah populernya disebut istri simpanan. Kebanyakan orang meyakini bahwa perkawinan di bawah tangan sah menurut Islam karena telah memenuhi rukun dan syaratnya, sekalipun perkawinan tersebut tidak dicatatkan di Kantor Urusan Agama. Akibat pemahaman tersebut maka timbul dualisme hukum yang berlaku di negara Indonesia ini, yaitu di satu sisi perkawinan itu harus dicatatkan di Kantor Urusan Agama dan disisi lain tanpa dicatatkan pun tetap berlaku dan diakui dimasyarakat.

Bertitik tolak dari uraian tersebut di atas, maka timbul permasalahan pokok yang hendak dipaparkan dalam tulisan ini yaitu: Apakah rukun perkawinan yang berlaku dan diyakini sekarang ini sudah final atau masih bisa diijtihadi ? Apakah perkawinan di bawah tangan sudah sesuai dengan maqâshid al-syarîah ? Siapakah yang berwenang atau yang berhak untuk menikahkan seseorang menurut hukum Islam?

\section{Mengenal Perkawinan di Bawah Tangan}

Perkawinan di bawah tangan atau yang dikenal dengan berbagai istilah lain seperti 'nikah bawah tangan', 'kawin siri' atau 'nikah sirri', adalah pernikahan yang dilakukan berdasarkan aturan agama atau adat istiadat dan tidak dicatatkan di kantor pegawai pencatat nikah (KUA bagi

${ }^{7}$ Abdul Gani Abdullah, Himpunan Perundang-undangan dan Peraturan Peradilan Agama, ( Jakarta: PT. Intermasa, 1991), h.,187 
yang beragama Islam, Kantor Catatan Sipil bagi non-Islam). ${ }^{8}$

Perkawinan dibawah tangan disebut juga perkawinan yang ilegal yakni perkawinan yang keberadaanya tidak diakui atau tidak sah menurut undang-undang yang berlaku dalam suatu negara. ${ }^{9}$

Menurut Ma’ruf Amin, Forum Ijtima’ Ulama Komisi Fatwa sengaja memakai istilah perkawinan di bawah tangan adalah untuk membedakan dengan perkawinan sirri yang sudah dikenal di masyarakat. Istilah ini lebih sesuai dengan ketentuan agama Islam. Jika nikah sirri (secret marriage), ${ }^{10}$ dalam pengertian nikah yang dilakukan hanya berdua saja, tidak memakai syarat dan rukun nikah lainnya, sehingga dapat dipastikan perkawinan semacam ini tidak sah. ${ }^{11}$

\section{Rukun dan Syarat Perkawinan}

Perkawinan dikatakan sah apabila perkawinan itu telah memenuhi rukun dan syarat-syaratnya. Rukun perkawinan sebagaimana tercantum dalam pasal 14 Kompilasi Hukum Islam adalah sebagai berikut: (1)Calon mempelai suami, (2)Calon mempelai istri, (3)Wali Nikah, (4)Dua orang saksi, (5)Ijab kabul. ${ }^{12}$

${ }^{8}$ Indosiar.com, Dampak Pernikahan Bawah Tangan Bagi Perempuan, http://www.indosiar. com/ragam/dampak-pernikahan-bawah-tangan-bagi-perempuan_21434.html, (diakses 1 Februari 2017).

${ }^{9}$ Lihat Departemen Pendidikan dan Kebudayaan, Kamus Bahasa Indonesia II (Jakarta: Pusat Pembinaan dan Pengembangan Bahasa, 1983), h.782. Lihat juga J.S. Badudu dan Sutan Muhammad Zain, Kamus Umum Bahasa Indonesia (Jakarta: Pustaka Sinar Harapan,2001), h.528.

${ }^{10}$ Menurut seorang ulama terkemuka yang pernah menjabat Rektor Universitas al-Azhar di Kairo Mesir, yaitu Mahmûd Syalthûth, ia berpendapat bahwa nikah sirri merupakan jenis pernikahan dimana akad atau transaksinya (antara laki-laki dan perempuan) tidak dihadiri oleh para saksi, tidak dipublikasikan (ilân), tidak tercatat secara resmi, dan sepasang suami isteri itu hidup secara sembunyi-sembunyi sehingga tidak ada orang lain selain mereka berdua yang mengetahuinya. Fuqahâ berpendapat nikah sirri seperti ini tidak sah (batal), karena ada satu unsur syarat sah nikah yang tidak terpenuhi yakni kesaksian. Jika dalam transaksi akad dihadiri dua orang saksi dan dipublikasikan secara umum, maka nikahnya tidak disebut sirri dan sah menurut syariat. Namun jika kehadiran para saksi berjanji untuk merahasiakan dan tidak mempublikasikannya, fuqahâ’ sepakat akan kemakruhannya. Mahmûd Shalthûth, al-Fatâwâ: Dirâsat li Musykilât al-Muslim al-Múashir fî Hayâtih al-Yaumiyyah Wâjib al-Ammah (Dâr al-Qalam, t.t), h. 268-269, dalam karangan Dadi Nurhaedi, Nikah di Bawah Tangan: Praktik Nikah Sirri Mahasiswa Jogja (Jogjakarta: Saujana, 2003), h. 23.

${ }^{11}$ Asrorun Ni'am Sholeh, Fatwa-Fatwa Masalah Pernikahan dan Keluarga, h. 147. Lihat juga di http://www. hukumonline. com/berita/baca/hol15651/pencatatan-nikah-akan-memperjelas-status. (di akses pada tanggal 1 Februari 2017).

${ }^{12}$ Direktur Pembinaan Badan Peradilan Agama Islam. Himpunan Peraturan Perundangundangan dalam Lingkungan Peradilan Agama. (Jakarta: 2001). h. 321 
Sedangkan Syarat perkawinan sebagaimana tercantum dalam pasal 6 UU. RI. Nomor 1 tahun 1974 adalah sebagai berikut: (1) Perkawina harus didasarkan atas persetujuan kedua calon mempelai, (2) Kedua mempelai mencapai umur 21 tahun, jika kurang dari umur 21 tahun harus mendapat izin dari ke dua orang tua, jka wanita kurang dari umur 16 tahun dan pria kurang dari umut 19 tahun, maka harus mendapat izin dari Pengadilan (dispensasi kawin), (3) Tidak ada larangan menurut hukum Islam. ${ }^{13}$

Masyarakat Muslim Indonesia sudah meyakini bahwa rukun perkawinan adalah sebagaimana tersebut di atas, sehingga perkawinan (pernikahan) yang sudah memenuhi rukun tersebut di atas, maka perkawinan tersebut sudah dikatakan sah menurut hukum Islam, padahal ulama mazhab berbeda pendapat mengenai rukun perkawinan itu sendiri diantaranya:

a. Menurut Imam Malik rukun pernikahan ada lima, diantaranya ;

1). Wali dari pihak perempuan,

2). Mahar (maskawin),

3). Calon mempelai laki-laki,

4). Calon mempelai perempuan,

5). Sighat akad nikah. ${ }^{14}$

b. Menurut Ulama Syafi'iyah rukun pernikahan ada lima, diantaranya:

1). Calon mempelai laki-laki,

2). Calon mempelai perempuan,

3). Wali,

4). Dua orang saksi,

5). Sighat akad nikah.. ${ }^{15}$

c. Menurut Ulama Hanafiyyah rukun perkawinan hanya ijab dan qabul saja. ${ }^{16}$

Imam Malik menjadikan mahar sebagai rukun perkawinan sedangkan saksi bukan sebagai rukun pekawinan, ulama Syafi'iyyah dua orang saksi

${ }^{13}$ Direktur Pembinaan Badan Peradilan Agama Islam. Himpunan Peraturan Perundangundangan dalam Lingkungan Peradilan Agama, h.133.

${ }^{14}$ Abdurrahman Ghazaly, Fiqh Munakahat, ( Jakarta: Prenada Media, 2003), h. 47-48

${ }^{15}$ Abu Yahya Zakariya Al-Anshari. Fathul Wahab. (Lebanon: Dar al-Fikri, tt), Juz 2, h. 34

${ }^{16}$ Abdurrahman Ghazaly. Figh Munakahat, h. 45. 
dijadikan sebagai rukun pernikahan sedangkan mahar bukan sebagai rukun pernikahan, begitu juga ulama Hanafiyah yang menyatakan bahwa rukun perkawinan hanya ijab qabul saja, sedangkan yang lainnya bukan sebagai rukun perkawinan. Imam Syafi'i sendiri dalam Al-'Umm tidak menjelaskan tentang rukun pekawinan. Dengan demikian dapat diketahui bahwa diantara ulama Mazhab sendiri tidak ada kesepakatan tentang rukun perkawinan, oleh karena itu rukun perkawinan yang sudah masyhur di masyarakat atau segaimana yang tercantum pada pasal 14 Kompilasi Hukum Islam belumlah final, tetapi ada kemungkinan untuk dirubah baik ditambah atau dikurangi sesuai dengan kebutuhan dan kemaslahatan bagi masyarakat itu sendiri.

Calon mempelai pria dan calon mempelai wanita dijadikan sebagai rukun perkawinan, bukan karena ada petunjuk dari Al-Qur'an atau AlSunnah, akan tetapi semata-mata hasil ijtihad ulama, Al-Qur'an dan AlSunnah tidak menjelaskan adanya calon mempelai pria dan calon mempelai wanita yang mengarah untuk dijadikan sebagai rukun pernikahan. Oleh karena itu Imam Hanafi tidak menjadikan calon mempelai pria dan calon mempelai wanita sebagai rukun perkawinan.

Sedangkan wali dari mempelai wanita dan dua orang saksi dijadikan sebagai rukun perkawinan karena ada petunjuk hadits Nabi yang berbunyi:

$$
\text { لَا نِكَاحَ الِاَّ بِوَلِيِّ وَشَاهِدَيْ عَدْلٍ (رواه احمد والاربعة) }
$$

Tidak sah nikah tanpa wali dan dua orang saksi yang adil. (HR. Ahmad dan Imam Empat). ${ }^{17}$

Ulama Syafi'iyyah dan Imam Hambali menerima hadits yang diriwayatkan oleh Imam Ahmad, dan menurut mereka hadits tersebut kuat, oleh karena itu wali dan dua orang saksi dijadikan sebagai rukun perkawinan, tetapi Imam Malik hanya menerima hadits tentang wali dan tidak menerima hadits tentang saksi, oleh karena itu Imam Malik menyatakan saksi tidak termasuk rukun perkawinan. Sedangkan Imam Hanafi menyatakan hadits tersebut kurang kuat, oleh karena itu Imam Hanafi menyatakan wali nikah dan dua orang saksi tidak dijadikan sebagai rukun perkawinan.

Ulama Syafi'iyyah telah menjadikan wali dan dua orang saksi sebagai

${ }^{17}$ Muhammad Ibnu Rusyd, Bidayatul Mujtahid .( Bairut, Libanon: Dar al-Fikri, tt). Juz 2. h. 9. 
rukun perkawinan serta Imam Malik menjadikan wali sebagai rukun perkawinan, oleh karena itu perlu dijelaskan pengertian wali dan dua orang saksi itu sendiri. Wali menurut bahasa artinya amat dekat atau yang melindungi, sedangkan yang dimaksud wali nikah adalah orang yang berhak untuk menikahkan seorang perempuan kepada pria pilihannya karena ada hubungan darah. Oleh karena itu orang yang tidak mempunyai hubungan darah tidak berwenang atau tidak berhak untuk menikahkan seseorang perempuan dengan pilihannya. Sebagaimana telah disepakati para ulama fiqh, urutan wali adalah dari yang paling dekat seperti ayah, kakek, saudara pria sekandung, saudara pria sebapak dan seterusnya, yang kesemuanya itu dari garis keturunan pria.

Yang jadi masalah adalah bagaimana jika wanita itu tidak mempunyai wali?, maka sesuai hadits Nabi dari Siti Aisyah yang berbunyi:

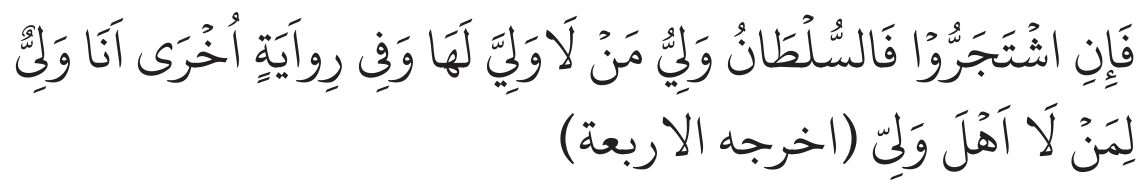

Apabila wali-wali itu menolak untuk menikahkannya, maka pemerintah (raja) yang menjadi wali bagi orang yang tidak mempunyai wali, dalam riwayat hadits lain disebutkan Nabi yang menjadi wali bagi orang yang tidak memiliki wali. (HR. Imam Empat) ${ }^{18}$

Dalam hadits di atas dijelaskan bahwa wali nikah bagi wanita yang tidak mempunyai wali adalah Nabi Saw sendiri, dalam hal ini Nabi Saw berkedudukan sebagai pemimpin, atau sultan (pemerintah) atau disebut juga dengan wali hakim. Pengertian sultan dalam negara kesatuan Republik Indonesia bisa diartikan Presiden, jadi yang berhak untuk menikahkan wanita yang tidak memiliki wali adalah Presiden, akan tetapi Presiden telah mendelegasikan kekuasaannya bagi yang beragama Islam kepada Kementrian Agama dalam hal ini Kantor Urusan Agama (KUA). Dengan

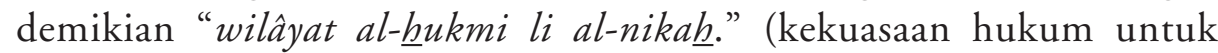
menikahkan) ada pada Kantor Urusan Agama, oleh karena itu tidak sah nikah seorang wanita yang dilakukan oleh tokoh masyarakan atau ulama tertentu disuatu daerah karena mereka tidak memiliki wilâyat al- $\underline{\text { ukmi }}$ li al-nikah. Begitu juga tidaklah sah seorang wali yang memiliki kekuasaan

${ }^{18}$ Muhammad Ismail Al-Kahlani., Subulus Salam, ( Bandung: CV. Dahlan, tt), Juz 3, h. 18 
untuk menikahkan putrinya mewakilkan kepada tokoh masyarakat atau ulama, kecuali dilakukan dihadapan Pejabat Pencatat Nikah (KUA) dan atas izin Pejabat tersebut.

Sedangkan dua orang saksi yang dimaksud disini adalah dua orang saksi yang adil. Untuk mengetahui serta menilai apakah saksi-saksi itu bisa berbuat adil atau tidak?, dalam hal ini harus ada suatu lembaga/institusi yang bertugas untuk mengontrol keadilan saksi-saksi tersebut. Oleh karena itu KUA adalah suatu lembaga yang sah untuk mengontrol dan menetapkan saksi-sakai dalam pernikahan, karena lembaga ini telah diberi wewenang oleh Sultan (Presiden) untuk menyelesaikan masalah pernikahan bagi orang yang beragama Islam. Dengan demikian dua orang saksi dalam pernikahan bukan sembarang saksi, tetapi saksi-saksi yang telah ditunjuk dan ditetapkan oleh Petugas Pencatat Nikah Kantor Urusan Agama pada saat akad pernikahan.

Imam Syafi'i menjelaskan "pernikahan harus disaksikan oleh dua orang saksi yang adil, apabila hanya satu saja saksi yang hadir maka pernikahan tersebut adalah batal, saksi-saksi tersebut adalah saksi-saksi yang telah ditunjuk oleh sultan, bukan sembarang saksi, karena sembarang saksi tidak bisa dijamin keadilannya. ${ }^{19}$

Dari uraian tersebut di atas, pada dasarnya rukun perkawinan yang lima sebagaimana telah dijelaskan di atas tidak disepakati oleh imam mazhab, hanya ijab qabul saja yang telah disepakati sebagai rukun perkawinan oleh sebagian besar ulama mazhab, sedangkan yang lainya masih diperselisihkan. Oleh karena masih diperselisihkan, maka dapat disimpulkan rukun perkawinan yang lima itu belum final (masih ijtihadi), oleh karenanya ada kemungkinan rukun pernikahan bisa bertambah atau bisa berkurang dari yang lima, sesuai dengan kebutuhan dan kemaslahatan umat manusia. Atas dasar itu menurut pandangan penulis rukun perkawinan itu ada enam, dengan menambahkan pencatatan sebagai rukun perkawinan.

Dasar pencatatan sebagai rukun perkawinan adalah sebagai berikut:

(1) Firman Allah dalam Surat Al-Nisâ' ayat 59 yang berbunyi:

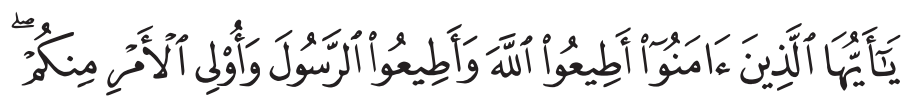

${ }^{19}$ Muhammad Idris Al-Syafi'i, Al-Umm. (Bairut, Libanon: Dar al- Fikri, tt). Jilid 3, h. 24. 
Hai orang-orang yang beriman, ta'atilah Allah dan ta'atilah Rasul (Nya), dan Ulil amri di antara kamu. ${ }^{20}$ (Q.S. Al-Nisa'4: 59)

Ahmad Musthafa Al-Maraghi menjelaskan yang dimaksud dengan "Ulil Amri" adalah pemerintah (Pemimpin), baik pemerintah pusat ataupun menerintah dibawahnya, dimana tugasnya adalah memelihara kemaslahatan umat manusia. Dengan demikian aturan-aturan yang dibuat oleh pemerintah untuk kemaslahatan manusia wajib ditaati selama aturanaturan tersebut tidak bertentangan dengan Al-Qur'an dan Al-Sunnah. ${ }^{21}$

Menurut Mujahid, Atha dan Hasan Basri yang dimaskud dengan "Ulil Amri" adalah pemimpin yang ahli dalam agama. Oleh karena itu aturan-aturan yang dibuat oleh pemimpin yang ahli dalam agama wajib ditaati, sedangkan aturan-aturan yang bertentangan dengan hukum Allah dan Rasul-Nya tidak perlu ditaati, sebagaimana disebutkan dalam hadits yang shahih yang diriwayatkan oleh Bukhari dan Muslim yang artinya " Sesungguhnya taat itu hanya untuk yang baik sedangkan untuk kemaksyiatan tidak wajib taat" 22

Dengan demikian yang dimaksud dengan "Ulil Amri" adalah pemimpin-pemimpin yang diangkat oleh masyarakat itu sendiri atau yang dinobatkan sebagai raja, untuk mengatur kehidupan masyarakat. Aturan-aturan yang dibuat oleh pemimpin atau raja untuk kemaslahatan manusia harus ditaati, selama aturan-aturan itu tidak bertentangan dengan Al-Qur'an dan Al-Sunnah. Aturan-aturan yang dimaksud adalah yang dibuat oleh pemerintah/raja, atau aturan-aturan yang dibuat oleh lembagalembaga tertentu/para ulama yang kemudikan dijadikan sebagai kebijakan dalam pemerintahannya.

Kalau dilihat dari ilmu ushul fiqh, firman Allah tersebut di atas mengandung arti amr (perintah), yaitu perintah untuk mentaati Allah, mentaati Rasul dan mentaati Pemimpin, sedangkan amr (perintah) ada yang mengandung wujûb (wajib), ada yang mengandung nadb (sunnah) dan ada juga yang mengandung jawâz (kebolehan). Untuk mengatahui

${ }^{20}$ Departemen Agama RI. Al-Qur'an dan Tarjemahannya, (Bandung: Gema Risalah Press, 1992). h. 128..

${ }^{21}$ Ahmad Musthafa Al-Maraghi. Tafsir Al-Maraghi. ( Makkah Al-Mukaramah: Al-Maktabah At-Tijaniyyah, tt). Jilid 2. Juz.2, h. 72.

${ }^{22}$ Ismail Ibnu Katsir, Tafsir al-Qur'an Ibnu Katsir,( Surabaya: Sirkatun Nuur Asiya ,tt), Juz 1, h. 518 . 
katagori perintah apakah mengandung wujûb (wajib), mengandung nadb (sunnah) atau mengandung jawâz (kebolehan), hal ini perlu diketahui dari kepentingan perintah itu sendiri, jika perintah itu kalau dijalankan akan membawa kemaslahatan kepada umat manusia dan kalau ditinggalkan akan membawa kemadharatan serta kekacauan kepada umat manusia, maka amr (perintah) itu menunjukkan wajib.

Sedangkan jika perintah itu ada qarînah ${ }^{23}$ lain yang menunjukan tidak mendesak dan tidak membawa kemadharatan kalau ditinggalkan, maka amr (perintah) itu menunjukan kepada sunnah atau kebolehan. Dengan demikian karena perintah pencatatan dalam perkawinan akan membawa kepada kemaslahatan bagi umat manusia serta akan membawa kepada kemadharatan jika ditinggalkan, maka dapat ditafsirkan perintah mentaati ulil amri dalam firman Allah tersebut di atas menunjukan kepada wajib.

\section{(2) Sunnah Rasul}

Banyak Sunnah Nabi yang menerangkan tentang perintah mentaati pemimpin, diantaranya hadits yang diriwayatkan dari Abu Hurairah Ra. ${ }^{24}$

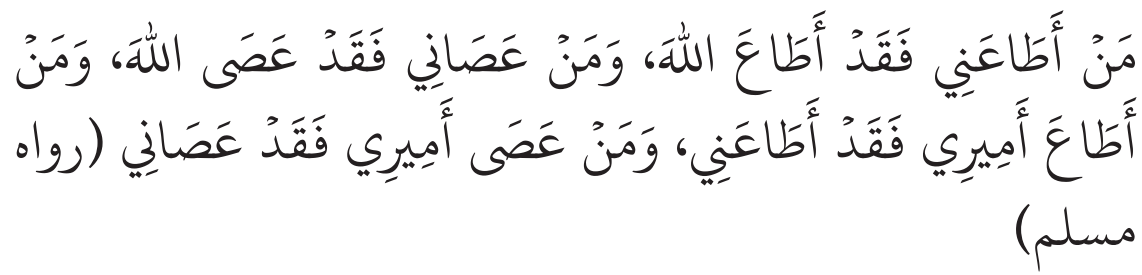

Barang siapa yang mentaatiku maka ia telah mentaati Allah, barang siapa yang membantah kepadaku maka ia telah membantah kepada Allah, barang siapa yang mentaati pemimpin maka ia telah mentaatiku, dan barang siapa yang membantah pemimpin maka ia telah membantah kepadaku. (HR. Muslim)

Hadits-hadits yang menerangkan tentang perintah mentaati pemimpin pada umumnya masih besifat umum, tetapi sudah dapat dipastikan yang dimaksud dengan mentaati pemimpin disini adalah apabila perintah-perintah itu tidak bertentangan dengan Al-Qur'an dan Al-Sunnah. Ulama telah

${ }^{23}$ Secara istilah, qarinah diartikan sebagai "tanda-tanda yang merupakan hasil kesimpulan hakim dalam menangani berbagai kasus melalui ijtihad". Lihat As'adullah Al-Faruq, Hukum Acara Peradilan Islam, Cet. I, (Yogyakarta: Pustaka Yustisia, 2009), h. 85.

${ }^{24}$ Imam Muslim, Shahih Muslim, (Bairut: Dâr Ihyyâ' at-Turâts al-'Araby, tt), juz 3, h. 1466 
sepakat bahwa aturan-aturan yang telah dibuat oleh pemimpin muslim di negara yang mayoritas penduduknya muslim wajib ditaati apabila perintah itu untuk kemaslahatan manusia serta tidak bertentangan dengan AlQur'an dan Al-Sunnah, sedangkan terhadap aturan-aturan yang dibuat oleh pemimpin yang non Muslim, ulama berbeda pendapat, sebagian golongan ada yang berpendapat boleh mentaati aturan-aturan yang dibuat oleh pemimpin yang non muslim jika aturan tersebut tidak bertentangan dengan Al-Qur'an dan Al-Sunnah, sedangkan sebagian lagi berpendapat tidak boleh mentaati aturan-aturan yang dibuat oleh pemimpin non muslim sekalipun aturan-aturan tersebut tidak bertentangan dengan Al-Qur'an dan Al-Sunnah, karena aturan-aturan yang dibuat oleh non muslim adalah batal. Dengan demikian dapat disimpulkan aturan-aturan yang dibuat oleh pemerintah Indonesia dalam hal ini Kementrian Agama yang mana aturan-aturan tersebut dibuat oleh orang-orang Muslim untuk kemaslahatan umat islam, maka peraturan-peraturan itu wajib untuk ditaati.

Pada zaman Rasulullah Saw setiap kejadian pernikahan, talak, ruju' dan lain sebagainya selalu dihadapkan kepada Rasulullah, kemudian Rasulullah menghukum begini dan begitu, ini menandakan bahwa setiap peristiwa perkawinan dan perceraian selalu diketahui oleh Rasulullah, karena kedudukan Rasulullah sebagai Ulama dan Umara. Memang pada zaman Rasulullah perkawinan dan perceraian tidak dicatatkan, hal itu dapat dimaklumi karena pada waktu itu umat Islam masih sedikit dan cukup hanya diingat saja oleh Rasulullah.

Pada zaman kekuasaan kerajaan, Islam semakin luas dan umat Islam semakin banyak, permasalahan-permasalahan umat Islam baik mengenai pidana maupun perdata selalu dihadapkan kepada pemerintah (raja), maka sejak zaman kerajaan Umayah maupun Abasiyah sudah memulai pencatatan mengenai keperdataan serta menyelesaikannya melalui pengadilan, terbukti dengan putusan-putusan Qadhi mengenai perdata, karena jika tidak dicatatkan dengan baik dan rapi akan menimbulkan kemadharatan bagi kelangsungan kehidupan rumah tangga.

Sedangkan pada zaman sekarang penduduk manusia sudah banyak sekali, maka jika perkawinan itu tidak dicatatkan akan terjadi kekacauan dan kemadharatan yang akan menimpa umat manusia, karena kemungkinan besar perkawinan itu tidak akan terkontrol, banyak orang kawin cerai-kawin cerai, atau telah berkali-kali menikah akan tetapi mengaku belum pernah menikah, yang pada akhirnya mengakibatkan kemadharatan yang amat besar 
bagi anak-anak yang dilahirkan dari perkawinan yang tidak dicatatkan, serta tidak diketahui siapa ayah kandung yang sebenarnya, karena tidak akan bisa diingat lagi siapa yang sudah menikah dan yang belum menikah, tetapi kalau dicatatkan akan diketahui pernikahan seseorang dan akan terkontrol serta dapat diketahui pula nama orang tua seseorang.

Dalam fikih Islam tidak mengenal adanya pencatatan perkawinan dan tidak ada syarat bahwa akad nikah itu harus dituliskan atau diaktekan ${ }^{25}$ walaupun ada ayat Al-Qur'an yang menganjurkan untuk mencatat segala bentuk transaksi muamalah. ${ }^{26}$ Namun agaknya masalah pencatatan perkawinan ini tidak hanya diperdebatkan apakah sebagai syarat sah atau syarat administratif. Tetapi bagaimana dibangun cara pandang baru dalam kerangka pembaharuan hukum keluarga Islam di Indonesia. Sampai saat ini menarik untuk menganalisis pendapat Atho' Muzhar yang mengatakan pencatatan perkawinan harus dilihat sebagai bentuk cara mengumumkan (mengillankan perkawinan). Lebih jauh dari pencatatan ini lebih maslahat terutama bagi wanita dan anak-anak. ${ }^{27}$

Menurut Ahmad Rofiq, menempatkan pencatatan perkawinan hanya sebagai syarat administratif sangat tidak menguntungkan upaya sosialisi Undang-Undang Pernikahan (UUP) di Indonesia. Padahal jika di lacak metodologinya, cukup jelas. Secara tekhnis para ulama ushul menyebutnya dengan al-Mashlahah al-Mursalah (public interest). ${ }^{28}$ Dengan adanya pencatatan perkawinan dan dengan status hukum yang jelas, maka berbagai bentuk kemudaratan seperti ketidakpastian status bagi wanita dan anak-anak dapat dihindari. ${ }^{29}$

${ }^{25}$ Khairuddin Nasution, Status Wanita di Asia Tenggara: Studi terhadap Perundang-undangan Pernikahan Muslim Kontemporer di Indonesia dan Malaysia (Jakarta-Leiden: INIS, 2002), 139.

${ }^{26}$ Amir Nuruddin dan Azhari Akmal Tarigan, Hukum Perdata Islamd di Indonesia (Jakarta: Fajar Interpratama Offset, 2004), 120. Lihat juga Eddie C. Y. Kuo and Riaz Hassan. "Some Social Concomitants of Interethnic Marriage in Singapore"Journal of Marriage and Family, Vol. 38, No. 3 (Aug., 1976), pp. 549-559. Di unduh dari http://www. jstor. org/stable/350423. pdf di akses 27 Januari 2015.

${ }^{27}$ M. Atho' Muzhar, Membaca Gelombang Ijtihad, Antara Tradisi dan Liberasi (Jakarta: Titian Ilahi Pers, 1998), 180.

${ }^{28} \mathrm{~J}$. Schacht menyatakan bahwa pinsip mashlahah menurut Abduh lebih diminati daripada penetapan hukum Islam secara harfiah dan prinsip mashlahah menjadikan Islam memiliki kesadaran akan realitas secara lebih maju daripada agama lain. Joseph Schacht, An Introduction to Islamic Law (London: Oxford Univercity Press, 1965), h. 62. Muhammad Khalid Mas'ud, Shatibis Philosophyof Islamic Law, (Kuala Lumpur: IBT, 1995), h.136.

${ }^{29}$ Ahmad Rofiq, Pembaharuan Hukum Islam di Indonesia (Yogyakarta: Gama Media, 2001), h.109. 
Lebih jelas lagi menurut Abdul Hakim, menempatkan pencatatan perkawinan sebagai syarat sah dapat dilakukan dengan penerapan ijtihâd shara' (ijtihad bentuk baru) yakni dengan menggunakan kaidah "menolak bahaya didahulukan atas mendatangkan kebaikan" untuk menjamin ketertiban dan kepastian hukum rakyatnya maka pemerintah dapat menetapkan aturan yang mendukung terciptanya ketertiban dan kepastian hukum sesuai dengan kaidah, suatu tindakan atau peraturan pemerintah, berintikan terjaminnya kemaslahatan rakyatnya. ${ }^{30}$

Ketentuan pencatatan perkawinan sebagai bagian dari rukun perkawinan sebagaimana disebutkan pada Bab III pasal 6 CLD (counter legal draft), secara konseptual merupakan formalisasi dari spirit dasar ketentuan UU No. 1/1974 dan KHI sebagai alat ukur sahnya perkawinan secara yuridis formal, ${ }^{31}$ walaupun pencatatan itu ditempatkan sebagai syarat yang bersifat administratif. Keharusan pencatatan dalam perkawinan bisa ditempatkan sebagai tindakan preventif dari kemungkinan lahirnya pelanggaran hukum berupa kekerasan dalam perkawinan baik dalam bentuk kekerasan fisik, psikis maupun pelantaran rumah tangga dengan payung yuridis yang otentik dan kuat yang dibuktikan dengan akte perkawinan. ${ }^{32}$

Oleh karena itu, masalah keharusan pencatatan perkawinan dalam konteks hukum Islam secara metodologis bisa masuk kategori sadd al-

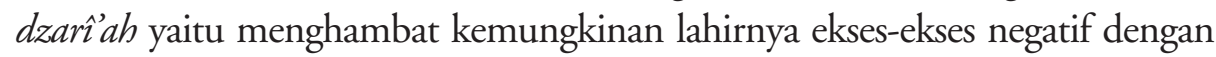
berpegang pada prinsip dar'u al-mafâsid muqaddamun 'alâ jalb al-mashâlih $\underline{1}^{33}$ (mencegah dampak negatif didahulukan daripada menarik kemaslahatan). Di samping pertimbangan sadd al-dzarîah, pelarangan nikah sirri didasarkan

${ }^{30}$ Abdul Halim, "Ijtihad Kontemporer: Kajian Terhadap Beberapa Aspek Hukum Keluarga Indonesia”, dalam Ainurrofiq (ed), Madzhab Jogja: Menggagas Ushul Fiqh Kontemporer (Yogyakarta: Ar-Ruzz, 2002), h. 240.

${ }^{31}$ Penempatan pencatatan sebagai sebagai bagian dari rukun pernikahan oleh perumus LCD tidak lebih sebagai upaya penegasan formal keharusan pencatatan dalam sebagaimana diatur UU No. 1/1974 pasal 2 dan Kompilasi Hukum Islam pasal 4, 5, 6, 7 yang kemudian ditarik pada tempat yang lebih tinggi yaitu sebagai rukun pernikahan dan tidak semata-mata keharusan administratif saja. Dengan demikian pencatatan pernikahan sebagai rukun tidak lebih sebagai pengembangan dari sesuatu yang secara material sudah ada untuk kemudian dikemas dengan baju yang baru. Ridwan, Membongkar Fikih Negara: Wacana Keadilan Gender dalam Hukum Keluarga Islam (Purwokerto: Pusat Sudi Gender STAIN Purwokerto, 2005), h. 143.

${ }^{32}$ Rebecca Probert. "The Impact of the Marrige Act of 1753: Was It Really "A Most Cruel Law for the Fair Sex"? Eighteenth-Century Studies, Vol. 38, No. 2 (Winter, 2005), pp. 247-262. Diunduh dari: http://www.jstor.org/stable/30053767.pdf di akses tanggal 27 Januari 2015.

${ }^{33}$ Amir Syarifuddin, Ushul Figh (Jakarta: Logos, 1999),h. 405. 
pada keharusan adanya ketaatan terhadap pemimpin Negara (ulil amri)..$^{34}$

Pencatatan perkawinan bisa dimaknai sebagai bagian dari intervensi negara dalam masalah perkawinan dalam rangka menciptakan tertib administrasi dan menjamin kepastian hukum. Dalam hal ini negara mempunyai otoritas untuk melakukan ini sebagaimana diteorikan oleh Mawardi bahwa Negara dibangun untuk meneruskan misi kenabian untuk menjaga agama ( harasat al-dîn) dan mengatur pranata sosial (siyasat al-dunya). ${ }^{35}$

Dengan demikian, pemerintah atau ulil amri sebagai pemegang kekuasaan politik melalui Dewan Perwakilan Rakyat (DPR) mempunyai otoritas untuk membuat paket undang-undang sebagai instrument hukum untuk mengatur masyarakat agar terjamin ketertiban sosial dalam melindungi hak-hak hukum masyarakat, khususnya mereka yang yang rentan menjadi korban (perempuan) secara adil. Dalam khazanah metodologi hukum Islam terdapat kaidah figh untuk melegitimasi otoritas pemerintah membuat paket undang-undang, asalkan dasar pijak perumusan undang-undang tersebut adalah untuk menciptakan kemaslahatan rakyatnya. Adapun kaidah fikihnya adalah: "Tasharruf al-Imâm Alâ al-Räiyyah Manûthun bi al-Mashlahah” artinya, kebijakan penguasa (pemerintah) terhadap rakyatnya haruslah didasarkan atas kemaslahatan. ${ }^{36}$ Oleh karena pencatatan pernikahan dapat menegakkan kemaslahatan bagi umat manusia, maka sudah sepatutnya pencatatan pernikahan dijadikan sebagai rukun perkawinan pada zaman sekarang ini, karena pada dasarnya pencatatan perkawinan itu ada dasar hukumnya dari Al-Qur'an dan Al-Sunnah serta dapat menegakan kemaslahatan bagi umat manusia.

\section{Maqâshid Al-Syarîah Perkawinan}

Tujuan perkawinan dalam pandangan Islam adalah untuk memenuhi perintah agama, dalam rangka mendirikan rumah tangga yang harmonis, sejahtra dan bahagia. Harmonis dalam hal menjalankan hak dan ke-

${ }^{34}$ QS. al-Nisâ’ [4]: 59.

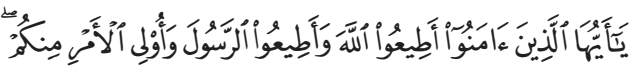

"Wahai orang-orang yang beriman, taatilah Allah dan taatilah Rasul (Nya), dan ulil amri di antara kamu...”.( QS. al-Nisâ' [4]: 59).

${ }^{35}$ Abi Hasan al-Mawardi, Kitâb al-Ahkâm al-Sulthâniyyah (Beirut: Dâr al-Fikr, tt.), h.5.

36 'Abdullah Ibn Said al-Hadhramî, Idhah al-Qawaiid al-Fiqhiyyah (Jiddah: al-Haramain, tt.), h. 62. Lihat pula Abi Bakr al-Suyuthî, Al-Asybâh wal-Nadhâir (Jakarta: Maktabah Nur Asiyah, tt.), h. 83. 
wajiban yang seimbang antara suami istri, sehingga tercipta kerelaan dan sepenanggungan dalam rumah tangga. Sejahtra dalam hal terpenuhinya kebutuhan-kebutuhan hajat hidup berumah tangga yang biasanya berbentuk materi, sehingga dengan meteri ini bisa membangun rumah tangga yang berkecukupan. Bahagia dalam hal terciptanya ketenangan lahir dan bathin, ketenangan lahir akan timbul bila mana telah terpenuhi kebutuhan lahir yang berupa sandang pangan dan papan, sedangkan ketenangan bathin akan timbul bila mana telah terpenuhi kebutuhan bathin yang berupa hubungan suami istri atau hubungan biologis.

Manusia diciptakan oleh Allah mempunyai tugas yang amat penting, yaitu sebagai khalîfah fi al-ardl, kedudukanya sebagai khalifah tidak lain adalah untuk menjalankan missi-missi Allah di muka bumi, karena manusia diciptakan untuk mengabdikan dirinya kepada sang Khaliq dengan segala aktivitas kehiduannya. Karena sangat pentingnya missi-missi Allah di muka bumi ini, maka Allah memerintahkan kepada manusia untuk memenuhi kebutuhan bilogisnya dengan jalan perkawina, sehingga dengan perkawinan akan melahirkan keturunan yang akan melanjutkannya missi Allah di muka bumi ini. Allah mengatur kehidupan manusia dengan jalan perkawinan, karena perkawinan dalam agama Islam merupakan tuntunan agama, sehingga tujuan perkawinan hendaknya ditujukan untuk memenuhi petunjuk agama.

Imam Ghazali dalam I $\underline{h} y \hat{a}$ ' 'Ulûmuddîn menyebutkan bahwa tujuan perkawinan adalah: (1). Untuk mendapatkan dan melangsungkan keturunan, (2). Untuk menyalurkan sahwatnya dan menumpahkan kasih sayang, (3). Untuk memelihara diri dari kejahatan dan kerusakan, (4). Menimbulkan kesungguhan untuk bertanggungjawab dalam memenuhi hak dan kewajiban serta memperoleh kekayaan yang halal, (5). Untuk membangun rumah tangga/masyarakat atas dasar cinta dan kasih sayang ${ }^{37}$

Pada intinya maqâshid al-syarîah dari perkawinan adalah agar manusia hidupnya damai penuh dengan kasih sayang satu dengan yang lainnya, karena unsur dari kejadian manusia adanya pemenuhan kebutuhan biologis untuk malanjutkan keturunan, sehingga dengan perkawinan itu manusia akan terhindar dari perbuatan yang keji dan kotor yang bisa menimbulkan kejahatan dan kerusakan. Keturunan yang diharapkan oleh syari'ah adalah keturunan yang dapat menjalankan aturan-arturan Allah yang berupa

${ }^{37}$ Imam Ghazali, Ihyya' 'Ulûm al-dîn, (Semarang: Usaha Keluarga,tt) Juz 2. h. 25. 
perintah dan larangan. Sebab terlaksananya perintah-perintah Allah akan terciptanya kemaslahatan dan kedamaian dalam dunia ini, sedangkan dengan tidak terlaksananya perintah-perintah Allah akan terciptnya kerusakan dan kemadharatan dalam dunia ini.

Seorang pria mempunyai naluri sex yang lebih dibandingkan dengan wanita, oleh karena itu Allah membolehkan seorang pria untuk beristri lebih dari satu orang istri sebagaimana disebutkan oleh Allah dalam surat Al-Nisa ayat 3. Dengan naluri biologis seorang pria boleh menikahi wanita kapan saja ia mau dan dimana saja ia kehendaki, selama istri itu tidak melebihi empat orang, dengan naluri biologisnya pula seorang pria akan berbohong bahwa ia belum beristri, atau sudah beristri tetapi belum melebihi dari empat istri.

Oleh karena itu tujuan syariah tidak akan tercapai jika tidak ada keterlibatan pihak lain yang berupa lembaga yang telah diberi wewenang oleh pemerintah untuk menanganinya. Dengan lembaga tersebut perkawinan seorang pria dengan seorang wanita akan tercatat rapi, sehingga tidak ada lagi penipuan dan kebohongan dalam perkawinan, yang kesemuanya itu akan merugikan pihak wanita.

Tujuan syariah lainnya adalah terpeliharanya turunan-turunan yang akan melanjutkan missi Allah di muka bumi, perkawinan seorang pria yang dilatar belakangi hanya karena kebohongan belaka atau karena memenuhi nafsu biologis saja, akan mengakibatkan tidak terpeliharanya turunanturunan baik dari segi pendidikan, agama ataupun mental, sehingga akan mengakibatkan timbulnya kerusakan dan kemadharatan bagi anak-anak itu sendiri. Dengan adanya pencatatan maka kedudukan anak serta status anak akan semakin jelas yang bisa diketahui turunannya, sehingga ia berhak untuk mendapatkan atau menuntut sesuatu dari ayahnya, sedangkan apabila perkawinan itu tidak dicatatkan maka hak-hak anak akan terabaikan.

Perkawinan di bawah tangan sebenarnya tidak sesuai dengan maqâshîd alsyarîa ${ }^{38}$ karena ada beberapa tujuan syari’ah yang dihilangkan, diantaranya:

${ }^{38}$ Maqâshîd al-Syarîah adalah tujuan-tujuan disyariatkannya hukum. Yakni mewujudkan kemaslahatan, baik dengan cara menarik manfaat (jalb al-manâfi') maupun mencegah kerusakan (dar'u al-mâfasid). Kemaslahatan akan terwujud jika lima unsur pokok (ushûl al-khamsah) dapat diwujudkan dan dipelihara. Kelima unsur pokok tersebut adalah al-dîn (agama), al-nafs (jiwa), al-'aql (akal), al-nasl (keturunan), dan al-mâl (harta). Lihat Abu Ishaq al-Syatibi, al-Muwâfaqat fî Ushûl al-Syariah, (Bairut: Dâr al-Kutub al-'Ilmiyyah, Juz II, 2003), h. 8 
(1)Perkawinan itu harus diumumkan (diketahui halayak ramai) ${ }^{39}$. Maksudnya agar orang-orang mengetahui bahwa antara A dengan B telah terikat sebagai suami istri yang sah, sehingga orang lain dilarang untuk melamar $A$ atau $B$, tetapi dalam perkawinan di bawahtangan, selalu disembunyikan agar tidak diketahui orang lain, sehingga perkawinan antara A dengan B masih diragukan, (2) Adanya perlindungan hak untuk wanita.Dalam perkawinan di bawahtangan pihak wanita banyak dirugikan hak-haknya, karena kalau terjadi perceraian pihak wanita tidak mendapatkan apa-apa dari mantan suaminya, (3) Untuk kemaslahatan manusia.Dalam perkawinan di bawah tangan lebih banyak madharatnya dari pada maslahatnya, seperti anakanak yang lahir dari perkawinan dibawahtangan lebih tidak terurus, sulit untuk bersekolah atau untuk mencari pekerjaan karena orang tuanya tidak mempunyai surat nikah dan seandainya ayahnya meninggal dunia/cerai, anak yang lahir di bawahtangan tidak mempunyai kekuatan hukum untuk menuntut harta warisan dari ayahnya. (4)Harus mendapat izin dari istri pertama. Perkawinan kedua, ketiga dan seterusnya yang tidak mendapat izin dari istri pertama biasanya dilakukan di bawahtangan, sehingga istri pertama tidak mengetahui bahwa suaminya telah menikah lagi dengan wanita lain, rumah tangga seperti ini penuh dengan kebohongan dan dusta, karena suami selalu berbohong kepada istri pertama, sehingga perkawinan seperti ini tidak akan mendapat rahmat dari Allah.

Dengan demikian dapat disimpulkan bahwa tujuan perkawinan dalam syari'ah adalah agar hidup manusia di dunia ini penuh dengan kedamaian dan kasih sayang antara yang satu dengan yang lainnya, manusia yang mempunyai tugas sebagai khalîfah fî al-ardl untuk tetap menjalankan misi-misi Allah di muka bumi ini dengan menjalankan aturan-aturan yang telah ditetapkan oleh Allah ataupun Rasul-Nya yang berupa Al-Qur'an dan Hadits, sehingga dunia ini penuh dengan kedamaian dan kemaslahatan bagi umat manusia. Akan tetapi kedamaian dan kemaslahatan tidak akan

39 Hal ini sebagaimana hadits Nabi yang telah diriwayatkan oleh Ahmad yang dishahihkan oleh al-Hakim, bunyi haditsnya sebagai berikut:

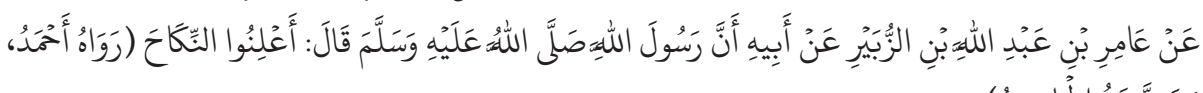

"Diriwayatkan dari Amir bin Abdillah bin Al-Zubair dari Ayahnya bahwasanya Rasulallah SAW. bersabda: "umumkanlah pernikahan kalian" (HR. Ahmad dan dishahihkan oleh al-Hakim). Lihat Maktabah Syâmilah, Subul al-Salâm, Juz 4, h. 451 
tercapai jika tidak ada aturan-aturan pendukung lainnya yang lebih spesifik yang berupa al-Maslahah al-Mursalah, oleh karena itu Pemerintah Republik Indonesia telah membuat aturan-aturan yang berupa UU. Nomor 1 tahun 1974, PP. nomor 9 tahun 1975, UU. Nomor 7 tahun 1989, Kompilasi Hukum Islam dan lain sebagainya.

\section{Tugas dan Kewenangan Menangani Perkawinan}

Sebagaimana telah disebutkan pada pasal 2 ayat (2) Undang-undang Nomor 1 tahun 1974 yaitu "Tiap perkawinan dicatat menurut peraturan perundang-undangan yang berlaku", atau sesuai dengan pasal 5 ayat (1) dan ayat (2) Kompilasi Hukum Islam/Inpres RI. Nomor 1 tahun 1991, ayat (1) berbunyi "Agar terjamin ketertiban perkawinan bagi masyarakat Islam harus dicatat, sedangkan ayat (2) berbunyi "Pencatatan perkawinan tersebut pada ayat (1) dilakukan oleh Pegawai Pencatat Nikah".

Pada ayat (1) pasal 5 KHI disebutkan ada kata harus dicatat, kata harus disini berarti wajib atau rukun, karena dengan pencatatan itu akan mendatangkan kemaslahatan, sedangkan kalau tidak dicatatkana akan mendatangkan kekacauan dan kemadharatan, mendirikan kemaslahatan dan menolak kemadharatan hukumnya wajib. Dengan demikian karena pencatatan perkawinan mendatangkan kemaslahatan, maka sudah seharusnya pencatatan perkawinan itu dijadikan salah satu rukun perkawinan pada zaman sekarang ini, oleh karena itu perkawinan yang tidak dicatatkan berarti tidak memenuhi rukun perkawinan, karena tidak memenuhi rukun perkawinan, maka sudah dipastikan perkawinan yang tidak dicatatkan tidak sah menurut hukum Islam. Pada ayat dua (2) Kompilasi Hukum Islam disebutkan "Sahnya pencatatan itu harus dilakukan oleh Petugas Pencatat Nikah (KUA)", analoginya jika pencatatan itu dilakukan oleh bukan Petugas Pencatat Nikah, maka nikahnya tidak sah, karena selain PPN (KUA) tidak memiliki kewenangan untuk mencatatkan atau melangsungkan pernikahan. Begitu juga pada pasal 6 ayat (1) KHI berbunyi "untuk memenuhi ketentuan pasal $5 \mathrm{KHI}$, setiap perkawinan harus dilangsungkan di hadapan dan di bawah pengawasan Pegawai Pencatat Nikah". Kata "harus" juga diartikan wajib, artinya perkawinan itu wajib dilakukan dihadapan Petugas Pencatat Nikah, oleh karena itu perkawinan yang dilakukan diluar Petugas Pencatat Nikah maka nikahnya tidak sah pula menurut hukum Islam. Kantor Urusan Agama (KUA) adalah lembaga 
yang telah ditunjuk (tauliyyah) oleh Presiden Republik Indonesia untuk menangani masalah perkawinan bagi orang yang beragama Islam, sehingga para Petugas Pencatat Nikah KUA telah disumpah oleh pemerintah agar mereka dapat menjalankan tugas sesuai yang diamanatkan dan sesuai dengan jabatan yang diembannya. Dengan tauliyyah itu KUA mempunyai kewenangan yang mutlak untuk menangani masalah pernikahan bagi yang beragama Islam, dengan demikian lembaga-lembaga lain baik yang dibuat oleh pemerintah ataupun lembaga swasta, golongan ataupun pribadi tidak mempunyai kewenangan untuk melaksanakan pernikahan.

Pada zaman daulat Umayyah organisasi negara dan susunan pemerintahan sudah sangat rapi, sehingga ada beberapa departemen yang membidangi masing-masing, diantaranya Al-Nidhâm al-Siyâsy (Organisasi Politik), Al-Nidhâm al-Irâdly (Organisasi Tata Usaha Negara), Al-Nidhâm alMâly (Organisasi Keuangan), Al-Nidhâm al- $\underline{H}$ arby (Organisasi Pertahanan), Al- Nidhâm al-Qadlầiy (Organisasi Kehakiman). Organisasi ini mempunyai tugas dan kewenangan yang berbeda, sehingga masing-masing organisasi tidak boleh mengurus bidang lain yang bukan menjadi kewenangannya. ${ }^{40}$ Pada masa ini pula organisasi kehakiman telah tersusun rapi perkara-perkara yang diputuskan oleh Pengadilan telah dicatatkan dan dibukukan dengan rapi. Dengan jelas pada zaman daulat Umayyah terutama pada zaman Khalifah Umar Bin Abdul Aziz sekitar tahun 99 hijriyah telah diadakan pencatatan yang sangat rapi, tujuannya agar segala urusan dapat dikontrol dengan baik sehingga kemaslahatan dan ketertiban warganya akan terjamin. Sudah dapat dibayangkan pada masa Khalifah Umar bin Abdul Aziz pencatatan sudah begitu ketat, padahal pada waktu itu penduduknya masih sedikit bila dibandingkan dengan sekarang, oleh karena itu pencatatan pada zaman sekarang ini sangat mendesak untuk dilakukan.

Penduduk Indonesia yang mencapai 205 juta lebih dan merupakan populasi Muslim terbesar di dunia, jika masalah perkawinan tidak dicatatkan dengan rapi dan tertib, akan menjadi preseden yang tidak baik bagi negara Islam lainnya di dunia, yang seharusnya Indonesia sebagai negara Muslim terbesar di dunia menjadi contoh yang baik bagi negara lainnya di dunia. Suatu saat kemadharatan akan timbul bagi bangsa Indonesia bila perkawinan tidak dicatatkan. Kerugian yang diakibatkan dari

${ }^{40}$ A. Hasymy, Sejarah Kebudayaan Islam. Bulan Bintang, (Jakarta: 1995). Cet Ke 5 ,h. 176 
perkawinan yang tidak dicatatkan adalah, pertambahan penduduk yang tidak terkontrol, kemiskinan akan bertambah, kawin cerai akan terjadi di mana-mana, hak-hak anak dan wanita akan terabaikan, pendidikan akan terbelakang dan pengangguran semakin bertambah.

Di Indonesia perkawinan di bawah tangan (kawin sirri) diakui keberadaannya, sehingga di Indonesia ada dua pilihan hukum untuk melangsungkan perkawinan (pernikahan). Pertama: pernikahan yang dilangsungkan melalui Pegawai Pencatat Pernikahan Kantor Urusan Agama, yang dikenal dengan perkawinan secara resmi. Kedua: perkawinan yang dilangsungkan di luar Pegawai Pencatat Pernikahan, biasanya dilakukan dihadapan tokoh masyarakat atau ulama, yang dikenal dengan perkawinan dibawah tangan/siri. Perkawinan dibawah tangan/siri biasanya dilakukan oleh pria yang ingin melangsungkan pernikahan untuk istri kedua dan seterusnya, karena untuk beristri lebih dari satu orang, seorang pria harus mendapatkan izin dari Pengadilan, sedangkan untuk mendapatkan izin dari Pengadilan harus ada beberapa syarat yang harus dipenuhi serta ada izin dari istri pertama. Oleh karena itu pria yang ingin beristri lebih dari satu orang mereka lebih suka mendatangi tokoh masyarakat/ulama karena tidak ada syarat-syarat yang ditentukan. Jika perkawinan di bawah tangan/ siri tidak dicegah, maka tokoh masyarakat/ustadz/orang-orang tertentu akan berlomba-lomba untuk menikahkan sebanyak mungkin, serta akan dijadikan sebagai ladang bisnis yang menggiurkan untuk mendatangkan uang, perkawinan seperti ini bukan yang dikehendaki oleh syari'ah, karena tidak akan mendatangkan kemaslahatan. Oleh karena itu perlu ditanamkan kepada masyarakat bahwa perkawinan di bawah tangan atau kawin siri tidak sah menurut hukum Islam, karena tokoh masyarakat/ustadz/ulama tidak mempunyai kewenangan untuk melangsungkan pernikahan.

\section{Penutup}

Rukun perkawinan sebagaimana yang telah masyhur di masyarakat adalah a) calon mempelai suami, b) calon mempelai istri, c) wali nikah, d) dua orang saksi, e) ijab qabul. Akan tetapi rukun perkawinan tersebut diperselisihkan oleh Imam mazhab yang empat (Maliki, Hanafi, Syafi'i dan Hambali), oleh karena masih diperselisihkan maka rukun perkawinan sebagaimana tersebut di atas belumlah final, bisa bertambah atau bisa berkurang sesuai dengan kondisi dan situasi masyarakat itu sendiri, 
yang mana dengan penambahan rukun tersebut bisa membawa kepada kemaslahatan. Pencatatan perkawinan membawa kepada kemaslahatan sedangkan kalau tidak dicatatkan akan membawa kepada kemadharatan, oleh karena itu menurut penulis rukun perkawinan ada enam dengan menambahkan pencatatan.

Tujuan perkawinan dalam syari'ah adalah agar hidup manusia di dunia ini penuh dengan kedamaian dan kasih sayang antara yang satu dengan yang lainnya (turunannya), dengan turunannya manusia yang mempunyai tugas sebagai khalîfah fî al-ardl akan tetap menjalankan misimisi Allah di muka bumi, dengan menjalankan aturan-aturan yang telah ditetapkan oleh Allah ataupun Rasul-Nya yang berupa Al-Qur'an dan Hadits, sehingga dunia ini penuh dengan kedamaian dan kemaslahatan bagi umat manusia. Akan tetapi kedamaian dan kemaslahatan tidak akan tercapai jika tidak ada aturan-aturan pendukung lainnya yang lebih spesifik yang berupa al-Maslahah al-Mursalah, oleh karena itu UU. Nomor 1 tahun 1974, UU. Nomor 7 tahun 1989, PP. nomor 9 tahun 1975, Kompilasi Hukum Islam dan lain sebagainya adalah aturan-aturan yang secara khusus untuk menjelaskan aturan-aturan Allah ataupun Rasulullah.

Kantor Urusan Agama (KUA) adalah lembaga yang telah ditunjuk (tauliyyah) oleh Presiden Republik Indonesia untuk menangani masalah perkawinan bagi orang yang beragama Islam. Petugas Pencatat Nikah KUA telah disumpah oleh pemerintah agar mereka dapat menjalankan tugas sesuai dengan yang diamanatkan dan sesuai pula dengan jabatan yang diembannya. Dengan tauliyyah tersebut KUA mempunyai kewenangan mutlak untuk menangani masalah pernikahan bagi yang beragama Islam, dengan demikian lembaga-lembaga lain baik yang dibuat oleh pemerintah ataupun lembaga swasta, golongan ataupun pribadi tidak mempunyai kewenangan untuk melaksanakan pernikahan, oleh karena itu perkawinan yang tidak dicatatkan di KUA tidak sah menurut hukum Islam.

Perkawinan yang tidak dicatatkan (dibawah tangan) akan menimbulkan kemadharatan bagi istri dan anak-anaknya, karena hak-hak istri, hak-hak anak-anaknya ataupun hak-hak suami istri akan terabaikan, perkawinan seperti ini bukan merupakan tujuan syari'ah. Sedangkan perkawinan yang dicatatkan di KUA akan menimbulkan kemaslahatan bagi istri dan anak-anaknya, karena hak-hak istri, hak-hak anak-anaknya ataupun hakhak suami istri akan terjamin keberadaannya, perkawinan seperti ini telah sesuai dengan tujuan syari'ah. 


\section{Pustaka Acuan}

Abdullah, Abdul Gani, Himpunan Perundang-undangan dan Peraturan Perradilan Agama, Jakarta: PT. Intermasa, 1991.

Abdurrahman Ghazaly, Fiqh Munakahat, Jakarta: Prenada Media, 2003

Al-Anshari, Abu Yahya Zakariya, Fath al-Wahab, Lebanon: Dar al-Fikri, tt.

al-Bâqi, Muhammad Fuâd Abd, al-Müjam al-Mufahras li al-Fâdz al-Qur'ân al-Karîm, Beirut: Dâr al-Fikr, 1987.

Al-Faruq, As’adullah, Hukum Acara Peradilan Islam, Cet. I, Yogyakarta: Pustaka Yustisia, 2009.

Al-Hadhramî, 'Abdullah Ibn Said, Idhâh al-Qawâid al-Fiqhiyyah, Jiddah: alHaramain, tt.

Al-Kahlani, Muhammad Ismail. Subulus Salam. Dahlan Bandung. Juz 3, tt.

Al-Maraghi, Ahmad Musthafa, Tafsir Al-Maraghi, Makkah Al-Mukaramah: Al-Maktabah At-Tijaniyyah, tt

al-Mawardi, Abi Hasan, Kitâb al-Ahkâm al-Sulthâniyyah, Beirut: Dâr al-Fikr, tt. al-Suyuthî, Abi Bakr, Al-Asybâh wal-Nadhâir, Jakarta: Maktabah Nur Asiyah, tt. Al-Syafi'i, Muhammad Idris, Al-Umm, Bairut, Libanon: Dar al- Fikri, tt.

Al-Syatibi, Abu Ishaq, al-Muwâfaqat fî Ushul al-Syariah, Bairut: Dâr al-Kutub al-'Ilmiyyah, Juz II, 2003.

Departemen Agama RI. Al-Qur'an dan Tarjemahannya, Bandung: Gema Risalah Press, 1992.

Departemen Pendidikan dan Kebudayaan, Kamus Bahasa Indonesia II, Jakarta: Pusat Pembinaan dan Pengembangan Bahasa, 1983.

Direktur Pembinaan Badan Peradilan Agama Islam. Himpunan Peraturan Perundang-undangan dalam Lingkungan Peradilan Agama, Jakarta: 2001. Fathullah, Ahmad Lutf, Potret Kehidupan Pribadi Dan Kehidupan Rasulullah Saw. Jakarta: Pusat Kajian Hadits.

Ghazali, Imam, Ihyya' 'Ulùm al-dîn, Semarang: Usaha Keluarga, tt Halim, Abdul, Ijtihad Kontemporer: Kajian Terhadap Beberapa Aspek Hukum Keluarga Indonesia, dalam Ainurrofiq (ed), Madzhab Jogja: Menggagas Ushul Figh Kontemporer Yogyakarta: Ar-Ruzz, 2002.

Hasymy, A., Sejarah Kebudayaan Islam. Jakarta: Bulan Bintang, 1995.

http://www.hukumonline.com/berita/baca/hol15651/pencatatan-nikah-akanmemperjelas-status.di akses pada tanggal 1 Februari 2017.

http://www.indosiar.com/ragam/dampak-pernikahan-bawah-tangan-bagiperempuan_21434.html, di akses pada tanggal 1 Februari 2017. 
Ibnu Katsir, Ismail, Tafsir al-Qur'an Ibnu Katsir, Surabaya: Sirkatun Nur 'Asiyah ,tt

Ibnu Majjah, Sunan Ibnu Majjah, Bairut, tt

Ibnu Rusyd, Muhammad, Bidayatul Mujtahid, Bairut, Libanon: Dar al-Fikri, tt. Kuo, Eddie C. Y. and Riaz Hassan. "Some Social Concomitants of Interethnic Marriage in Singapore"Journal of Marriage and Family, Vol. 38, No. 3 Aug., 1976.

Mas'ud, Muhammad Khalid, Shatibis Philosophyof Islamic Law, Kuala Lumpur: IBT, 1995.

Muslim, Imam, Shahih Muslim, Bairut: Dâr Ihyâ' at-Turâts al-Araby, tt.

Muzhar, M. Atho', Membaca Gelombang Ijtihad, Antara Tradisi dan Liberasi, Jakarta: Titian Ilahi Pers, 1998.

Nasution, Khairuddin, Status Wanita di Asia Tenggara: Studi terhadap Perundang-undangan Pernikahan Muslim Kontemporer di Indonesia dan Malaysia, Jakarta-Leiden: INIS, 2002.

Nurhaedi, Dadi, Nikah di Bawah Tangan: Praktik Nikah Sirri Mahasiswa Jogja, Jogjakarta: Saujana, 2003.

Nuruddin, Amir dan Azhari Akmal Tarigan, Hukum Perdata Islamd di Indonesia, Jakarta: Fajar Interpratama Offset, 2004.

Probert, Rebecca, The Impact of the Marrige Act of 1753: Was It Really "A Most Cruel Law for the Fair Sex"? Eighteenth-Century Studies, Vol. 38, No. 2 , Winter, 2005.

Ridwan, Membongkar Fikih Negara: Wacana Keadilan Gender dalam Hukum Keluarga Islam, Purwokerto: Pusat Sudi Gender STAIN Purwokerto, 2005.

Rofiq, Ahmad, Pembaharuan Hukum Islam di Indonesia, Yogyakarta: Gama Media, 2001.

Schacht, Joseph An Introduction to Islamic Law, London: Oxford Univercity Press, 1965.

Shalthûth, Mahmûd, al-Fatâwâ: Dirâsat li Musykilât al-Muslim al-Mu'âshir fì Hayâtih al-Yaumiyyah Wâjib al-Ammah, Dâr al-Qalam, t.t

Sholeh, Asrorun Ni'am, Fatwa-fatwa Masalah Pernikahan dan Keluarga, Jakarta: eLSAS, 2008.

Syarifuddin, Amir, Ushul Figh, Jakarta: Logos, 1999.

Zain, Sutan Muhammad dan J.S. Badudu, Kamus Umum Bahasa Indonesia, Jakarta: Pustaka Sinar Harapan, 2001. 